\title{
The reinforcing potentials of Velvet tamarind seed shell as filler in natural rubber compounds
}

\author{
Benedict Eluoyibo OKOH, Emmanuel OSABOHIEN* and \\ Sunny Honesty Okobia EGBOH \\ Department of Chemistry, Delta State University, Abraka, Nigeria. \\ *Corresponding author; E-mail: osabohieneemma@yahoo.com
}

\begin{abstract}
This work focused on the development of a reinforcing filler from renewable natural plant resources as part of the ongoing search for environmental friendly fillers that will substitute synthetic reinforcing fillers such as carbon black and silica in rubber manufacturing. The cure characteristics, physico-mechanical and equilibrium swelling properties of natural rubber, Standard Nigerian Rubber $\left(\mathrm{SNR}_{10}\right)$ vulcanizates separately filled with commercial grade carbon black (CB), N330 and pulverized natural plant material, Velvet tamarind (VT), seed shell were investigated. The results of the analyses showed that the scorch and cure times decreased while the maximum torques increased with increasing filler loading for both filled-SNR ${ }_{10}$ vulcanizates. The tensile strengths of both VT-filled and CB (N330) filled-SNR ${ }_{10}$ vulcanizates increased to $30 \mathrm{phr}$ and $40 \mathrm{phr}$ respectively and decreased with increasing filler loading. The modulus at $100 \%$ strain, specific gravity, abrasion resistance and hardness increased while elongation at break, equilibrium swelling and rebound resilience decreased with increasing filler loading for both filled-SNR 10 vulcanizates. The results showed that Velvet tamarind seed shell manifested a reinforcing effect on the $\mathrm{SNR}_{10}$ compounds but lower than that of $\mathrm{CB}$ (N330) filler.

() 2014 International Formulae Group. All rights reserved.
\end{abstract}

Keywords: Natural rubber, fillers, reinforcement and vulcanizate properties.

\section{INTRODUCTION}

Polymers have been known to form a class of materials used for their bulk properties. The bulk properties of a polymer are those properties that dictate how the polymer actually behaves on a microscopic scale. They include the tensile and tear strengths, abrasion resistance, modulus, resilience, hardness, ageing behaviour, specific gravity, gas and solvent permeability, among others (Bhatnagar, 2004). These properties are crucial in almost all engineering and technical applications of polymer products. However, it has been severally documented that raw natural rubber and many synthetic elastomers lack the necessary physical and mechanical properties needed for their wide range of possible applications. For instance, raw natural rubber and most synthetic elastomers have low strength and elasticity exhibited over a narrow range of temperature. Also, raw natural rubber has been found to degrade or change its properties in the presence of air, light and at elevated 
temperatures (Bhatnagar, 2004). All these factors would limit the uses and applications of raw polymer in service. To meet their service requirements, these bulk properties of the raw polymer can be improved by the incorporation of a variety of additives or compounding ingredients to the base polymer during processing. It has been shown that without these ingredients, few polymers are adequate for only trivial applications (Billmeyer, 1984; Boonstra, 1984). Additives facilitate the mixing and processing behaviour of polymers, make their vulcanization easier, increase the stability and durability of polymer products under variable temperature conditions, and permit a wide range of modifications of vulcanizate properties and their adoption to multitude of service requirements. The basic additives include vulcanizing agents, activators, accelerators, anti-degradants, fillers, processing aids, retarders and miscellaneous ingredients. Apart from the vulcanization system, the use of fillers is of utmost importance in order to achieve the desired properties of vulcanizates (Osabohien and Egboh, 2007; Osabohien, 2010).

Fillers affect the property spectrum of polymeric materials. Two types of fillers namely reinforcing and non-reinforcing fillers, are known (Osabohien and Egboh, 2007, 2008). A reinforcing filler increases the viscosity of polymer compounds and improves the mechanical properties of vulcanizates while a non-reinforcing filler leads to increases in viscosity and may not improve the mechanical properties but add bulk and can be used in low cost products. Carbon black is one of the oldest and most widely used reinforcing filler in natural rubber compounds. However, many research and development efforts have increased since the last two decades to develop and utilize materials from renewable resources such as natural plant materials while not compromising the properties of the vulcanizates. The reinforcing fillers from natural sources offer intrinsic properties and are renewable, relatively low cost, biodegradable, fairly high specific modulus and their use may serve as a means of converting waste agricultural products to wealth. Furthermore, it has been reported that natural plant materials and fibre-reinforced biocomposites are light in weight, have high physico-mechanical properties, easily recyclable and exhibit high resistance to corrosion and weather changes, biodegradable and low cost, hence, are environmental friendly (Pranut et al., 2001; Ray et al., 2001a; Nishino et al., 2003; Wang et al., 2003; Imanah and Okieimen, 2004; Sogbaike et al., 2005; Mathew et al., 2006; Osabohien et al., 2007; Osabohien and Egboh, 2007, 2008; Abubakar et al., 2012; Chaiwat et al., 2013).

Velvet tamarind (Dialium guineese, wild), belonging to the family, leguminosae is a wild tropical fruit-bearing plant with small grape-size edible fruits which have brown, thin, brittle inedible shells. Each fruit has one or two hard, flat, round, brown seeds that resemble the water melon seed. The fruit pulp has pleasant sour taste. In Nigeria, the fruits are sold in local markets between January and April of each year (Obasi et al., 2013).

The purpose of this research study is to explore the possibility of using Velvet tamarind seed shell as alternative filler to carbon black in natural rubber compounds. The study investigated the cure characteristics, physico-mechanical and equilibrium swelling properties of natural rubber compounds filled with Velvet tamarind (VT) seed shell and commercial grade carbon black, CB (N330).

\section{MATERIALS AND METHODS Materials}

The materials used for this study include, Velvet tamarind (VT) seed shells obtained from local farmers at Abavo, Delta State, Nigeria. Standard Nigerian Rubber $\left(\mathrm{SNR}_{10}\right)$ from Footwear Accessories, Manufacturing and Distribution (FAMAD), Benin City, Edo State, industrial grade carbon black, CB (N330), from Nigeria National 
Petroleum Corporation (NNPC), Warri, industrial grade compounding additives, rubber testing equipment from the Department of Polymer Technology, Auchi Polytechnic, Auchi, Edo State, Nigeria, were used as supplied. Kerosene and diesel oil were obtained from a local petrol filling station in Agbor, Delta State, Nigeria.

\section{Preparation and characterization of VT seed shell, CB (N330) and $\mathrm{SNR}_{10}$ \\ Velvet tamarind seeds were shelled} with hands and the shells were dried to a constant mass in an oven maintained at $80^{\circ} \mathrm{C}$ for a few hours. The dried shells were ground into powder by means of the Corona grinding machine. The pulverized specimen was screened through a sieve of mesh size $200 \mu \mathrm{m}$.

The sieved VT seed shell and CB (N330) were characterized in terms of their moisture content, loss on ignition, iodine adsorption number, density, $\mathrm{pH}$ of aqueous slurries and metallic and non-metallic contents using standard testing methods (Vogel, 1964; Christian, 1980; ASTM DI510, 1983). The natural rubber, $\mathrm{SNR}_{10}$, was characterized in terms of dirt content, ash content, nitrogen content, volatile matter, Mooney viscosity and Plasticity Retention Index (PRI) using standard techniques (ASTM D389-99, 1993, SAR, 1984, RRIM, 1989).

\section{Compounding and curing of the $\mathrm{SNR}_{10}$ mixes}

Table 1 shows the formulation of the natural rubber compounds using efficient vulcanization $(\mathrm{EV})$ system. In the recipe, the contents of the experimental VT filler were varied from $0,10,20,30,40,50,60$, and 70 parts per hundred (phr) of rubber whereas the other additives were kept constant. Each of the formulation was masticated and mixed with the compounding ingredients on a laboratory size $\left(160 \times 320 \mathrm{~mm}^{2}\right)$ two-roll mill maintained at $80{ }^{\circ} \mathrm{C}$. The cure characteristics of the unvulcanized samples were determined by means of the Monsanto rheometer, MDR 2000 model. The compounded natural rubber was cured by compression moulding in a steam heated, hydraulically operated press with a pressure of $150 \mathrm{~kg} / \mathrm{cm}^{2}$ at a temperature of $185{ }^{\circ} \mathrm{C}$ using the respective cure times obtained from the Monsanto rheographs.

\section{Determination of the physico-mechanical and equilibrium swelling $\left(S_{\text {eq }}\right)$ properties of vulcanizates}

The tensile properties (tensile strength, modulus and elongation at break) of the vulcanizates were measured with the Monsanto Instron 4301 Tensometer at a crosshead speed of $500 \mathrm{~mm} / \mathrm{min}$ using the dumbbell shaped test specimens in accordance with the procedure described in ASTM D412 (1983). The Wallace Croydon resiliometer 2A was used to measure the rebound resilience while the specific gravity and hardness of the vulcanizates were determined by Monsanto Densitron 2000 and Monsanto Duratron 2000 respectively. The abrasion resistance was determined by means of the Akron brader (BS, 1982).

The equilibrium swelling $\left(\mathrm{S}_{\mathrm{eq}}\right)$ properties of the natural rubber vulcanizates in organic solvents such as diesel oil, petrol and benzene were determined by gravimetric methods (BS, 1982; Imanah and Okieimen, 2004; Osabohien et al., 2007). Known weights of the test specimens were carefully cut into square shape and immersed in plastic bottles containing the solvents under investigation and tightly covered to exclude air and set aside at room temperature of about $25^{\circ} \mathrm{C}$. Each of the samples was removed from the containers, at a regular time interval, dried between filter papers, reweighed and immediately returned to the containers. This process of removing the samples from the containers, drying, reweighing and returning to the containers was continued until no noticeable change in weight was observed on the third day. The weight of each test sample after swelling was expressed as a percentage:

$\%$ Equilibrium swelling $=\frac{W_{2}-W_{1}}{W_{1}} \times 100$ 
(Where $\mathrm{W}_{1}$ and $\mathrm{W}_{2}$ are the initial and final weights of each sample before and after swelling respectively).

\section{RESULTS}

Table 2 summarizes the physicochemical characteristics of the natural rubber, Standard Nigerian Rubber $\left(\mathrm{SNR}_{10}\right)$ in comparison with other known standard rubbers, Standard African Rubber $\left(\mathrm{SAR}_{10}\right)$ and Standard Malaysian Rubber $\left(\mathrm{SMR}_{5}\right)$. The dirt, ash, Nitrogen and volatile matter contents, plasticity retention index (PRI) and Mooney viscosity of the rubbers were presented. Table 3 presents the physicochemical properties of the fillers, Velvet tamarind (VT) seed shell and carbon black, N330. The measured properties include; moisture content, loss on ignition, iodine adsorption number, $\mathrm{pH}, \mathrm{Mg}, \mathrm{Na}, \mathrm{K}, \mathrm{Fe}$, Chloride contents, density and particle size ranges of the fillers.

Tables 4 and 5 showed the cure characteristics of the fillers, CB (N330) and VT seed shell. The scorch time, cure time and maximum torque values at different, $0-70$ phr filler loadings, were presented.

The physico-mechanical properties of the $\mathrm{SNR}_{10}$ vulcanizates, the CB (N330)-filled and VT seed shell-filled $\mathrm{SNR}_{10}$ vulcanizates were summarized in Tables 6 and 7. The tensile strength, modulus, elongation at break, specific gravity, rebound resilience, abrasion resistance, hardness, equilibrium swelling in diesel oil, petrol and benzene solvents were reported.

Table 1: Recipe for the formulation of $\mathrm{SNR}_{10}$ compounds.

\begin{tabular}{lc}
\hline Ingredient loading & phr \\
\hline $\mathrm{SNR}_{10}$ & 100.0 \\
Zinc oxide & 4.0 \\
Stearic acid & 2.0 \\
Filler & $0.0-70.0$ \\
Processing oil & 2.0 \\
CBS & 2.0 \\
TMQ & 1.5 \\
Sulphur & 1.5 \\
\hline \multicolumn{2}{c}{ CBS = N- Cyclohexyl benzothiazyl sulphenamide } \\
TMQ = 2,2,4-trimethyl - 1,2-dihydroquinoline
\end{tabular}

Table 2: Physico-chemical characteristics of $\mathrm{SNR}_{10}$, Standard African Rubber $\left(\mathrm{SAR}_{10}\right)$ and Standard Malaysian Rubber $\left(\mathrm{SMR}_{5}\right)$.

\begin{tabular}{lccc}
\hline Natural Rubber & SNR $_{\mathbf{1 0}}$ & SAR $_{\mathbf{1 0}}$ & SMR $_{\mathbf{5}}$ \\
\hline Dirt content (\%) & 0.03 & 0.02 & 0.05 \\
Ash content (\%) & 0.02 & 0.32 & 0.50 \\
Nitrogen content (\%) & 0.41 & 0.23 & 0.70 \\
Volatile matter (\%) & 0.25 & 0.40 & 1.00 \\
Plasticity Retention Index (PRI) & 70.86 & 67.0 & - \\
Mooney Viscosity ML $(1+4) 100{ }^{\circ} \mathrm{C}$ & 85.00 & 70.00 & 60.00 \\
\hline
\end{tabular}


Table 3: Physico-chemical characteristics of CB (N330) and Velvet tamarind (VT) fillers.

\begin{tabular}{lcc}
\hline Filler & CB (N330) & VT seed shell \\
\hline \% Moisture Content at $120{ }^{\circ} \mathrm{C}$ & 1.30 & 5.40 \\
\% Loss on ignition at $1000{ }^{\circ} \mathrm{C}$ & 95.00 & 78.70 \\
Iodine adsorption number $(\mathrm{mg} / \mathrm{g})$ & 78.50 & 53.40 \\
$\mathrm{pH}$ of aqueous slurry & 6.80 & 5.40 \\
Magnesium $(\mathrm{ppm})$ & trace & 64.30 \\
Sodium $(\mathrm{ppm})$ & trace & 58.50 \\
Potassium $(\mathrm{ppm})$ & trace & 19.61 \\
Iron $(\mathrm{ppm})$ & trace & 40.70 \\
Chloride $(\mathrm{ppm})$ & trace & 16.10 \\
Density $\left(\mathrm{g} / \mathrm{cm}^{3}\right)$ & 1.80 & 1.10 \\
Particle size range & $30-35 \mathrm{~nm}$ & $15-200 \mu \mathrm{m}$ \\
\hline
\end{tabular}

Table 4: Cure characteristics of $\mathrm{SNR}_{10}$ compounds filled with $\mathrm{CB}$ (N330).

\begin{tabular}{lcccccccc}
\hline Filler $($ phr) & $\mathbf{0}$ & $\mathbf{1 0}$ & $\mathbf{2 0}$ & $\mathbf{3 0}$ & $\mathbf{4 0}$ & $\mathbf{5 0}$ & $\mathbf{6 0}$ & $\mathbf{7 0}$ \\
\hline Scorch time, $\mathrm{ts}_{2}(\mathrm{~s})$ & 33.40 & 31.70 & 30.50 & 28.80 & 28.00 & 27.30 & 26.50 & 25.20 \\
Cure time, $\mathrm{t}_{90}(\mathrm{~s})$ & 48.20 & 46.40 & 45.30 & 43.20 & 42.00 & 41.80 & 41.00 & 40.50 \\
Maximum torque, $\mathrm{T}_{\max }(\mathrm{lb}-\mathrm{in})$ & 6.90 & 8.31 & 10.22 & 11.40 & 12.53 & 12.80 & 13.10 & 13.60 \\
\hline
\end{tabular}

Table 5: Cure characteristics of SNR10 compounds filled with VT seed shell.

\begin{tabular}{lcccccccc}
\hline Filler $(\mathbf{p h r})$ & $\mathbf{0}$ & $\mathbf{1 0}$ & $\mathbf{2 0}$ & $\mathbf{3 0}$ & $\mathbf{4 0}$ & $\mathbf{5 0}$ & $\mathbf{6 0}$ & $\mathbf{7 0}$ \\
\hline Scorch time, $\mathrm{ts}_{2}(\mathrm{~s})$ & 33.40 & 33.00 & 32.60 & 31.80 & 30.40 & 29.60 & 29.10 & 28.30 \\
Cure time, $\mathrm{t}_{90}(\mathrm{~s})$ & 48.20 & 47.80 & 46.40 & 45.80 & 44.20 & 43.50 & 42.10 & 42.00 \\
Maximum torque, $\mathrm{T}_{\max }(\mathrm{lb}-\mathrm{in})$ & 6.90 & 7.80 & 8.63 & 9.45 & 11.10 & 12.33 & 12.40 & 12.73 \\
\hline
\end{tabular}

Table 6: Physico-mechanical properties of $\mathrm{SNR}_{10}$ compounds filled with $\mathrm{CB}$ (N300).

\begin{tabular}{lcccccccc}
\hline Filler (phr) & $\mathbf{0}$ & $\mathbf{1 0}$ & $\mathbf{2 0}$ & $\mathbf{3 0}$ & $\mathbf{4 0}$ & $\mathbf{5 0}$ & $\mathbf{6 0}$ & $\mathbf{7 0}$ \\
\hline Tensile strength (MPa) & 8.15 & 15.20 & 24.38 & 31.80 & 36.10 & 32.41 & 28.60 & 24.60 \\
Modulus, M100 (MPa) & 0.68 & 1.39 & 1.86 & 2.78 & 3.10 & 4.18 & 5.72 & 5.93 \\
Elongation at break (\%) & 6.70 & 530 & 511 & 482 & 450 & 370 & 286 & 250 \\
Specific gravity & 1.011 & 1.012 & 1.020 & 1.025 & 1.030 & 1.046 & 1.074 & 1.120 \\
Rebound Resilience (\%) & 80.60 & 76.50 & 73.00 & 72.40 & 65.20 & 60.10 & 56.80 & 55.00 \\
Abrasion resistance index & 40.00 & 41.00 & 42.00 & 42.00 & 43.00 & 44.00 & 44.00 & 45.00 \\
Hardness (IRHD) & 39.00 & 41.00 & 43.00 & 45.00 & 50.00 & 54.00 & 56.00 & 58.00 \\
${ }^{*} \mathrm{~S}_{\mathrm{eq}}$ Diesel oil (\%) & 280.0 & 150.2 & 110.4 & 89.1 & 76.3 & 72.5 & 68.1 & 64.3 \\
${ }^{*} \mathrm{~S}_{\mathrm{eq}}$ Petrol (\%) & 360.0 & 178.0 & 130.0 & 118.3 & 98.1 & 96.3 & 85.4 & 89.8 \\
${ }^{*} \mathrm{~S}_{\mathrm{eq}}$ Benzene (\%) & 540.0 & 293.1 & 268.3 & 221.5 & 178.7 & 152.3 & 143.8 & 142.7 \\
\hline${ }^{*} \mathrm{~S}_{\mathrm{eq}}=$ Equilibrium swelling & & & & & & & &
\end{tabular}


Table 7: Physico-mechanical properties of SNR ${ }^{10}$ compounds filled with VT filler.

\begin{tabular}{lcccccccc}
\hline Filler (phr) & $\mathbf{0}$ & $\mathbf{1 0}$ & $\mathbf{2 0}$ & $\mathbf{3 0}$ & $\mathbf{4 0}$ & $\mathbf{5 0}$ & $\mathbf{6 0}$ & $\mathbf{7 0}$ \\
\hline Tensile strength (MPa) & 8.15 & 8.56 & 9.80 & 10.86 & 10.47 & 9.74 & 6.82 & 5.93 \\
Modulus, M100 (MPa) & 0.68 & 0.71 & 0.74 & 0.78 & 0.81 & 0.86 & 0.98 & 1.23 \\
Elongation at break (\%) & 670 & 580 & 560 & 520 & 475 & 460 & 409 & 350 \\
Specific gravity & 1.011 & 1.011 & 1.011 & 10.11 & 1.012 & 1.013 & 1.014 & 1.014 \\
Rebound Resilience (\%) & 80.60 & 67.2 & 56.40 & 53.80 & 52.60 & 49.00 & 48.30 & 45.00 \\
Abrasion resistance index & 40.00 & 40.00 & 40.00 & 40.20 & 40.50 & 40.80 & 40.90 & 41.00 \\
Hardness (IRHD) & 39.00 & 38.00 & 39.00 & 40.00 & 40.50 & 42.00 & 43.60 & 45.00 \\
${ }^{*} \mathrm{~S}_{\text {eq }}$ Diesel oil (\%) & 280.0 & 268.0 & 247.0 & 202.0 & 198.50 & 186.0 & 163.0 & 145.0 \\
${ }^{*} \mathrm{~S}_{\mathrm{eq}}$ Petrol (\%) & 360.0 & 341.0 & 31200 & 296.0 & 246.0 & 210.0 & 197.0 & 171.0 \\
${ }^{*} \mathrm{~S}_{\mathrm{eq}}$ Benzene (\%) & 540.0 & 456.00 & 410.0 & 398.0 & 350.0 & 330.0 & 250.0 & 220.0 \\
\hline
\end{tabular}

${ }^{*} \mathrm{~S}_{\mathrm{eq}}=$ Equilibrium swelling

\section{DISCUSSION}

Physico-chemical properties of the $\mathrm{SNR}_{10}$ The data in Table 2 summarizes the physical prosperities of the $\mathrm{SNR}_{10}$ under study. The values of the physical properties of the $\mathrm{SNR}_{10}$ compared favourably with those of other standard natural rubbers such as Standard African Rubber and Standard Malaysian Rubber (RRIM, 1989; SAR, 1998; Akinlabi and Egbon, 2003). The high values of the plasticity retention index (PRI) and Mooney Viscosity indicate a high resistance of the $\mathrm{SNR}_{10}$ vulcanizates to ageing and flow respectively (Akinlabi and Egbon, 2003; Osabohien and Egboh, 2007).

\section{Physico-chemical properties of the fillers}

The results of the analyses shown in Table 3 revealed that VT filler has a higher moisture content compared to CB (N330) filler. High moisture content in a filler often leads to High filler dispersion in the polymer matrix resulting in a weak filler-polymer matrix adhesion hence poor mechanical strength properties of the vulcanizates (Pranut et al., 2001; Ray et al., 2001a; Wang et al., 2003; Puglia et al., 2005; Osabohien et al., 2006). The CB (N330) filler has higher weight loss on ignition at $1000{ }^{0} \mathrm{C}$ than the seed shell of Velvet tamarind (VT) suggesting that $\mathrm{CB}$
(N330) has a higher content of carbon or carbonaceous materials than the natural plant filler, VT seed shell. According to Horn (1982), carbon black consists of 90-99\% elemental carbon in addition to small quantities of combustible materials like sulphur, oxygen, halogens and organic compounds. It has been shown that the amount of carbon in a carbonaceous filler is a measure of its reinforcing effect; the higher the carbon content of a carbonaceous filler, the greater is its reinforcing potential (Osabohien et al., 2007; Osabohien, 2010). The results further showed that CB (N330) has higher iodine adsorption number thus indicating that it has a larger surface area (smaller particle size) than the VT filler. The surface area of a filler is the most important factor that determines its reinforcing effect while other filler related factors such as shape, structure, $\mathrm{pH}$, surface activity and porosity act to modify or complement this effect of particle size on elastomers (Boonstra, 1984; Asore, 2000). The results further showed that the aqueous slurry of VT filler was more acidic than that of CB (N330). It has been shown that the acidity of a filler influences both the crosslinking reaction during vulcanization and filler-rubber matrix interactions (Boonstra, 1984). According to 
Boonstra (1984), highly acidic fillers give little reinforcement and are prone to scorching. It has been shown that highly acidic fillers retard both the scorch time and cure time leading to poor mechanical properties of natural rubber vulcanizates (Iyasele and Okieimen, 2004). The results also showed the various metallic and non-metallic constituents of VT seed shell. The presence of these surface groups has been shown to influence the surface reactivity of a filler and hence it's reinforcing ability (Iyasele and Okeimen, 2004; Osabohien et al., 2006).

\section{Cure characteristics of $\mathrm{SNR}_{10}$ compounds}

Tables 4 and 5 summarize the results of analyses of the cure characteristics of the natural rubber $\mathrm{SNR}_{10}$ compounds filled with CB (N330) and VT seed shell at different filler loadings. The results showed that the scorch times and cure times of both CB (N330)- filled and VT- filled $\mathrm{SNR}_{10}$ vulcanizates decreased while the maximum torques increased with increasing filler loading. These findings are consistent with previous research reports (Iyasele and Okieimen, 2004; Osabohien et al., 2007; Osabohien and Egboh, 2007; Mohamad et al., 2008). These behaviours are attributed to filler related parameters such as surface area, particle size, humidity, $\mathrm{pH}$, moisture content, metal and metal oxide contents, acid content and the type of accelerator used for compounding. The higher cure and scorch times of VT-filled compared to CB (N330)filled $\mathrm{SNR}_{10}$ vulcanizates may be due to the, smaller surface area, higher acidic, metallic and moisture contents of the VT seed shell filler.

The increase in maximum torques with increase in filler content implies a good fillerrubber matrix adhesion and a good interfacial bonding between the filler and matrix to form crosslinks which restricted the free mobility of the polymer chains. The higher maximum torque values of $\mathrm{CB}$ (N330) -filled $\mathrm{SNR}_{10}$ vulcanizates could be attributed to the smaller particle size and larger surface area of $\mathrm{CB}$ (N330) compared to the VT filler (Table 3).

\section{Physico-mechanical properties of $\mathrm{SNR}_{10}$ vulcanizates}

Tables 6 and 7 summarize the physicomechanical properties of $\mathrm{SNR}_{10}$ vulcanizates filled separately with CB (N330) and VT seed shell at different filler loadings. The results showed that the tensile strengths of both $\mathrm{CB}$ (N330) and VT-filled $\mathrm{SNR}_{10}$ vulcanizates increased to optimum levels at $40 \mathrm{phr}$ and 30 phr respectively above which they decreased with increasing filler content. This behaviour may be due to the phenomenon of "phase inversion" and agglomeration effect (Osabohien and Egboh, 2007; Mohamad et al., 2008). The filler agglomerate is a domain that acts as an obstacle to filler dispersion, it increases with increasing filler loading and thus lowers the filler- rubber matrix interactions as the ratio of filler to the rubber matrix becomes too high hence the observed decrease in tensile strength after exceeding the optimum levels of filler loadings.

The results, however, revealed that VT seed shell filler manifested lower reinforcing potential than $\mathrm{CB}(\mathrm{N} 300)$ as shown by the lower tensile strength, torque, modulus at $100 \%$ strain, hardness and specific gravity but higher elongation at break and rebound resilience. These observations may be attributed to the larger partied size, smaller surface area, higher acidic $(\mathrm{pH})$ content, higher tendency to agglomerate and higher moisture content of the VT filler as compared with $\mathrm{CB}(\mathrm{N} 330)$ filler which may have led to poor filler dispersion and poor filler-rubber matrix interactions resulting in lower degree of crosslinking in VT - filled vulcanizates. The higher elongation at break and higher rebound resilience of the VT-filled $\mathrm{SNR}_{10}$ vulacanizates implies that their products would be less rigid and would be expected to have low hysteresis and heat build-up, while the lower specific gravity suggests that the VT-filled $\mathrm{SNR}_{10}$ products would be lighter in weight than the $\mathrm{CB}(\mathrm{N} 330)$ - filled $\mathrm{SNR}_{10}$ products. These observed gradations in the physico-mechanical properties of the $\mathrm{SNR}_{10}$ vulcanizates are consistent with the 
observations made earlier in previous research studies (Pranut et al., 2001, Imanah and Okieimen, 2004; Osabohien et al., 2006; Osabohien and Egboh, 2007; Mohamad et al., 2008; Osabohien, 2010).

The results further showed that the percentage equilibrium swelling for both $\mathrm{SNR}_{10-}$ filled systems decreased with increasing filler content thus suggesting an increase in crosslink density as the filler loading increased. The higher the crosslink density the lower the swelling of the $\mathrm{SNR}_{10}$ vulcanizates (George and Thomas, 2001). Thus equilibrium swelling in organic solvents depends on the nature of the filler and solvent, the crosslink density, extent of filler dispersion and the filler-rubber matrix compatibility (George and Thomas, 2001, Osabohien et al., 2007, 2011). The highest percentage equilibrium swelling in the unfilled $\mathrm{SNR}_{10}$ compounds may be due to lowest crosslinks, so that the solvent molecules readily diffused through the rubber membranes to react with the rubber molecules to form solution. The decrease in percentage equilibrium swelling with increasing filler loading for both vulcanizate systems may be due to increasing degree of crosslinking which acts to compact the free volume in the polymer and thus reduced the diffusion rate of the solvent molecules through the polymer interface. The observed higher percentage equilibrium swelling values of VT- filled $\mathrm{SNR}_{10}$ vulcanizates as compared to $\mathrm{CB}$ (N330)- filled types is due to its higher moisture content, higher acidity, lower structure, and larger particle size (Table 3). All these factors probably weakened the VTrubber compatibility and hence reduced the number of crosslinks so that there were lesser restrictions to the diffusion of the organic solvent molecules through the polymer membrane. It was also observed that the percentage equilibrium swelling was highest in benzene and least in diesel oil. This was probably due to the differences in molecular mass and diffusion coefficient. Benzene consists of single molecules with lower molecular mass (74 g) while kerosene and diesel oil are mixtures of hydrocarbons in the range $\mathrm{C}_{10}-\mathrm{C}_{14}$ (for kerosene) and $\mathrm{C}_{14}-\mathrm{C}_{19}$ (for diesel oil), therefore, benzene would be expected to diffuse faster than kerosene and diesel oil Diesel oil with the highest average molecular mass would diffuse slowest relative to kerosene and benzene. Similar observations were made by previous researchers (George and Thomas, 2001; AbuAbdeen and Abdel-Ghani, 2001; Okieimen and Imanah, 2005; Osabohien et al., 2011).

\section{Conclusion}

This research is another contribution to the ongoing search for environmental friendly fillers from renewable natural plant resources that can substitute or compliment the conventional carbon black and synthetic inorganic fillers. The cure characteristics, physico-mechanical and equilibrium swelling properties of natural rubber, $\mathrm{SNR}_{10}$ vulcanizates separately compounded with commercial grade carbon black (N330) and Velvet tamarind (VT) seed shell fillers were investigated. The results revealed that VT seed shell manifested a reinforcing effect on the $\mathrm{SNR}_{10}$ vulcanizates, but its reinforcing potential is lower than that of CB (N330). This may be due to its higher moisture content, larger particle size, smaller surface area and higher acidity. These defects can be corrected by employing modern methods of wet and dry grinding and carbonization techniques to improve the surface area of the locally sourced filler. By these processes, the strength properties of the locally filled vulcanizates could be enhanced to optimum, desirable levels.

\section{REFERENCES}

Abu-Abdeen M, Abdel-Ghani SA. 2001. Swelling and Electrical Properties of rubber Vulcanizates loaded with paraffin wax. J. Appl. Polym. Sci., 81: 3169-3177.

Abubakar MAI, Ahmed S, Kuntjoro W. 2012. Effect of Epoxidized Natural rubber on Mechanical properties of epoxy 
Reinforced Kenaf Fibre Composites. Pertanika J. Sci. Technol., 20(1): 129137.

Akinlabi AK, Egbon EE. 2003. Investigations into factors affecting production of Quality Crumb Rubber in Nigeria. Advances in Nat. App. Sci. Res., 1(1):166175.

Asore EJ. 2000. An Introduction to Rubber Technology. Joseg Books Ltd: Benin City, Nigeria; 1-141.

ASTM D1510. 1983. Standard Test Methods for Iodine Adsorption Number. American Society for Testing and Materials: West Conshohocken, PA.

ASTM D1638-99. 1983. Standard Test Method for Tensile Properties of Elastomers. American Society for Testing and Materials: West Conshohocken, PA.

Bhatnagar MS. 2004. A Textbook of Polymer Chemistry and Technology (vol. 2). S Chand and Co. Ltd: New Delhi; 1-138.

Billmeyer Jr FW. 1984. Textbook of Polymer Science $\left(2^{\text {nd }}\right.$ edn). Wiley Interscience: New York; 1-550.

Boonstra BB. 1984. Reinforcement by fillers. In Rubber Technology ( $2^{\text {nd }}$ edn), Morton M (ed). Van Nostrand Co.: New York; 56-108.

BS. 1982. British Standard Methods of Testing Vulcanized Rubber; BS 903 Part A9-16.

Chaiwat R, Wasaphon W, Apikiat S, Yupoporn R. 2013. Cogon grass fibreEpoxidized Natural Rubber composites. Adv. Mater. Res., 747: 375-378.

Christian GD. 1980. Analytical Chemistry. John Wiley and Sons Inc.: New York; 400-415.

George SC, Thomas S. 2001. Transport Phenomena through polymeric systems. Prog. Polym. Sci., 26: 985- 1017.

Horn JB. 1982. Materials for compounding and Reinforcement. In Rubber Technology and Manufacture, Blow CM, Hepburn C (eds). Butterworth Scientific: New York; 202-264.
Imanah JE, Okieimen FE. 2004. Studies on the Mechanical Properties of Natural Rubber Reinforced with Agricultural byproducts. Proceedings of $27^{\text {th }}$ Int. Conf. of Chem. Soc. Nig.: Benin City. Nigeria; 317-322.

Iyasele JU, Okieimen FE. 2004. Cure characteristics and Rheological Properties of Melon seed shell-filled Natural Rubber. Proceedings of $27^{\text {th }}$ Int. Conf. Chem. Soc. Nig.: Benin City, Nigeria; 272-277.

Mathew L, Joseph KU, Joseph R. 2006. Swelling behaviour of Isora/Natural Rubber composites in oils used in Automobiles. Bull. Mater. Sci., 29(1): 9199.

Mohamad N, Maditar A, Ghazali MJ, Muhd D, Azhari CH. 2008. The effect of filler on Epoxidized Natural Rubber- Alumina Nanoparticle composites. Euro J. Sci. Res., 24(2): 538-547.

Nishino T, Hirao, K, Katera M, Nakamae K, Inagaki H. 2003. Kenaf Reinforced Biodegradable composites. Comp. Sci. Technol., 63:1281-1286.

Obasi NE, Okorocha C, Orisakwe OF. 2013. Production and Evaluation of Velvet tamarind (Dialium guineese, wild) Candy. Eur. J. Food Sci. Technol., 1(1): $1-8$.

Okieimen FE, Imanah JE. 2005. Physicomechanical and equilibrium swelling Properties of Natural Rubber filled with Rubber seed shell carbon. J. Polym. Mater., 22(4): 409- 416.

Osabohien E, Egboh SHO. 2007. Cure Characteristics and physico-mechanical properties of Natural Rubber filled with seed shells of Cherry (Chrysophyllum albidum). J. Appl. Sci. Environ. Manage, 11(2): 430-48.

Osabohien E, Egboh SHO. 2008. Utilization of Bowstring Hemp fiber as filler in Natural Rubber Compounds. J. Appl. Polym. Sci., 107: 210-214.

Osabohien E, Egboh SHO, Okoh BE. 2006. The Cure Characteristics and Physico- 
mechanical properties of Natural Rubber filled with pineapple leaf fibre. Biosci. Biotechnol. Res. Asia, 4(1):111-116.

Osabohien E, Egboh SHO, Okoh BE. 2007. Cure, Physico-mechanical and Equilibrium swelling properties of Groundnut shell filled Natural Rubber. Biosci. Biotechnol. Res. Asia, 4(1a): 161168.

Osabohien E. 2010. Potential of carbonized cherry seed shell as filler in Natural Rubber Vulcanizates. J. Polym. Mater., 27(4): 389 - 399.

Osabohien E, Okoh BE, Imanah JE, Egboh SHO. 2011. The Effects of Epoxidation on the Potentials of Red earth-Natural rubber composites. Nigerian J. Polym. Sci. Technol., 7(1): 85-100.

Pranut P, Prakaipech P, Saowaroj C. 2001. Using water-hyacinth fibre as a filler in Natural Rubber. J. Sci. Res., 26(1): 12-18.

Puglia D, Biaglotti J, Kenny JM. 2005. Applications of Natural Reinforcements in Composite Materials for Automotive Industry. J. Nat. Fibre, 3: 23-65.

Ray D, Sarlear BK, Rana AK, Bose NR. 200la. Effect of Alkali Treated Jute
Fibres on composite properties. Bull. Mater. Sci., 24(2): 129-135.

RRIM. 1989. Test Methods for Standard Malaysian Rubber. Rubber Research Institute of Malaysia Bull., 7: 9-40.

Sogbaike OE, Okieimen FE, Edojariogba PO. 2005. Effect of substitution of N330 carbon black with carbonized plantain peels on Cure characteristics, Physicomechanical and Swelling properties of Natural Rubber Vulcanizates. Chem. Technol. J., 1: 24-29.

SAR. 1998. Standard African Rubber (SAR) Manual 2: Specifications and Test Methods.

Vogel AI. 1964. A Textbook of Quantitative Inorganic Analysis Including Elementary Instrumental Analysis. Longmans Group: London; 100-140.

Wang B, Ponigrahi S, Tabil L, Crerar W, Powell T, Kolybaba M, Sokhansanj S. 2003. Flax fibre-reinforced Thermoplastic Composites, Paper presented at the 2003 CSAE/ASAE Annual Int. Meeting, Furgo, USA, Oct. 3-4: 1-14. 